\title{
PML/RARA Fusion Protein
}

National Cancer Institute

\section{Source}

National Cancer Institute. PML/RARA Fusion Protein. NCI Thesaurus. Code C53622.

A fusion protein (797 aa, $106 \mathrm{kDa}$ ) that is encoded by the PML/RARA fusion gene. This protein contains the B-box and the RING-finger domain from protein PML and the DNAbinding domain, ligand binding domain and coactivator recognition site from the retinoic acid receptor alpha protein. 